\title{
Sedimentation and pedogenic features in a clay deposit in Quadrilátero Ferrífero, Minas Gerais, Brazil
}

\author{
MARIA-DO-CARMO SANTOS and ANGÉLICA F.D.C. VARAJÃO \\ DEGEO/EM/UFOP, Campus Universitário, Morro do Cruzeiro 35400-000 Ouro Preto, MG, Brasil \\ Manuscript received on August 4, 2003; accepted for publication on October 1, 2003; \\ presented by ADOLPHO J. MeLFI
}

\begin{abstract}
The clay deposit of Caxambu Hill occurs in a NW/SE oriented graben originated by syntectonic sedimentation during Cenozoic. Four facies were identified (fragmentary, nodular, massive and friable) and their differentiation is related to gravity mass-flow processes. The fragmentary facies is composed of extraclast fragments of the local Paleoproterozoic basement and sand size quartz-grains dispersed in a kaolinite-muscovite-goethitehematite matrix. The nodular facies is constituted by lithorelictal and pedorelictal nodules dispersed in a similar matrix as in the fragmentary facies. The massive facies is characterized by quartz grains dispersed in a kaolinite, hematite and goethite matrix with minor amounts of muscovite. The friable facies differs from the massive facies by its channel morphology, higher quartz and kaolinite content and the presence of millimetric clay-balls.

The fragmentary facies is considered as deposited during the early stage of opening of the basin. After that, under sub-arid conditions, the slumping of lateritic materials from the surrounding regolith led to the formation of the nodular and massive facies. The friable facies was originated by the action of unidirectional flow that reworking the clayey sediments. The increasing of kaolinite content towards the top is related to the chemical weathering action after the deposition of the sediments.
\end{abstract}

Key words: kaolinite, lithofacies, micromorphology, gravity mass flow, chemical weathering.

\section{INTRODUCTION}

Deposits generated by gravity mass-flow processes are texturally immature and comprise poorly sorted and immature sediments dispersed in a mud matrix. These debris flows can be further subdivided into grain flow or mudflow (cohesive debris flow, Lowe 1982), occurring either in subaerial or subaqueous environments (Jonhson 1970, 1984, Middleton and Hampton 1973). Several sedimentary deposits are formed by these processes, such as alluvial fans, fan-deltas, turbidites, colluvials, talus, etc. In spite

Correspondence to: Angélica F.D.C. Varajão

E-mail: angelica@degeo.ufop.br of the widespread occurrence of these processes in depositional systems, their characterization is not always obvious in highly weathered terrains in which iron mobilization and pedogenic mechanisms can homogenize the materials, leading to the formation of apparently massive clayey facies.

The evolution of a weathering mantle depends on the climate zone in which they formed. In intertropical regions the weathered mantle is relatively thick and chemically highly evolved with the formation of laterites. In typical well preserved lateritic profile a vertical succession of horizons or group of horizons occurs (Tardy 1969, Tardy and 
Nahon 1985, Nahon 1986) and comprises: 1) coarse grained saprolite or saprock; 2) fine grained saprolite; 3) pedolith comprising mottled clay zone and nodular horizons with $\mathrm{Fe}$ - and $\mathrm{Al}$ accumulation. The coarse grained saprolite forms the basal horizon in which relict fragments of all sizes and some primary minerals remain unweathered. The fine grained saprolite is the horizon in which most primary minerals have been altered to secondary minerals, such as kaolinite and iron oxyhydroxides, but the original rock fabric remains preserved. In the pedolith, the pre-existing macrostructure of the parent rock is destroyed, with the formation of ferruginous patches (mottled clay zones) and ferruginous nodules (nodular horizon). Indurated nodules become more numerous towards the top, coalescing into indurated cuirasse with conglomeratic structure. Towards the top of the conglomeratic iron crust, a cortex grows around the nodules by the rehydration and replacement of Al-hematite by Al-goethite resulting in the formation of pisolitic structure. The geochemical degradation of the pisolitic iron crust lead to the formation of a ferruginous pebbly horizon. So the lateritic profile results of the progressive development of each horizon by the transformation of the immediately underlied horizon.

The present study is a contribution to understanding the origin of the clayey deposit from Caxambu Hill. The investigations were based on sedimentological and pedological field observations and, mineralogical and micromorphological analysis, supported by X-ray diffraction (XRD), differential thermal and gravimetric analysis (DTADGA), and optical and scanning electron microscope (SEM).

\section{LOCALIZATION AND GEOLOGICAL SETTING}

The Quadrilátero Ferrífero $(\mathrm{QF})$ is a mountainous region comprised of Precambrian rocks, with altitudes ranging from 650 to $2.000 \mathrm{~m}$ and covering an area of nearly $7.000 \mathrm{~km}^{2}$, located in the centersoutheast of Minas Gerais State, southeastern Brazil (Figure 1). The geomorphologic features of the
Quadrilátero Ferrífero are related to structural and lithologic controls (Varajão 1991) with three main units: the summit or high slope (with altitudes over $1.500 \mathrm{~m}$ ), the hill slope, corresponding to the intermediate unit (with altitudes ranging from 800 to $1.400 \mathrm{~m}$ ) and the depressions or low slope (with altitudes varying from 1.200 to $1.400 \mathrm{~m}$ ). Orographic influences account for a mean annual temperature of $22^{\circ} \mathrm{C}$ and rainfall of $1500 \mathrm{~mm}$. June is the coldest month (mean $17^{\circ} \mathrm{C}$ ), but maximum of up $25^{\circ} \mathrm{C}$ occurs in January. The vegetation expresses variations of environmental conditions within each landform compartment.

The geologic architecture of the Quadrilátero Ferrífero defines mainly dome-and-keel structures formed by domes of Archean basement (e.g. Bação Metamorphic Complex) surrounded by keels (troughs) containing the Archean Rio das Velhas and the Paleoproterozoic Minas Supergroups (Alkmin and Marshak 1998). Keels include large first-order synclines, such as the Dom Bosco syncline at the southern portion of the QF (Figure 1).

The clayey deposit of Caxambu Hill, located near to the city of Ouro Preto, is inserted in the Dom Bosco syncline trough which is composed by Paleoproterozoic rocks (Minas Supergroup-Piracicaba Group) comprising quartzites, ferruginous quartzites, phyllites, carbonatic phyllites, dolomites and schists.

The Dom Bosco syncline is a structure with W-E orientation and has an extension of $80 \mathrm{~km}$ and a width of nearly $10 \mathrm{~km}$. Santos (1998) and Santos et al. $(1999,2000)$ observed that during the Tertiary small grabens were generated in this syncline and sediments were deposited by gravitational process forming several clayey deposits as that of Caxambu hill.

Clayey deposits were initially proposed by Guild (1957) as mudstone to define the aluminous clay massive occurrences present in the Quadrilátero Ferrífero. Santos (1998) and Santos et al. (1999, 2000) suggested that the association of these clayey materials with quartz grains and lithic fragments should be defined as diamictite. Beyond of this 


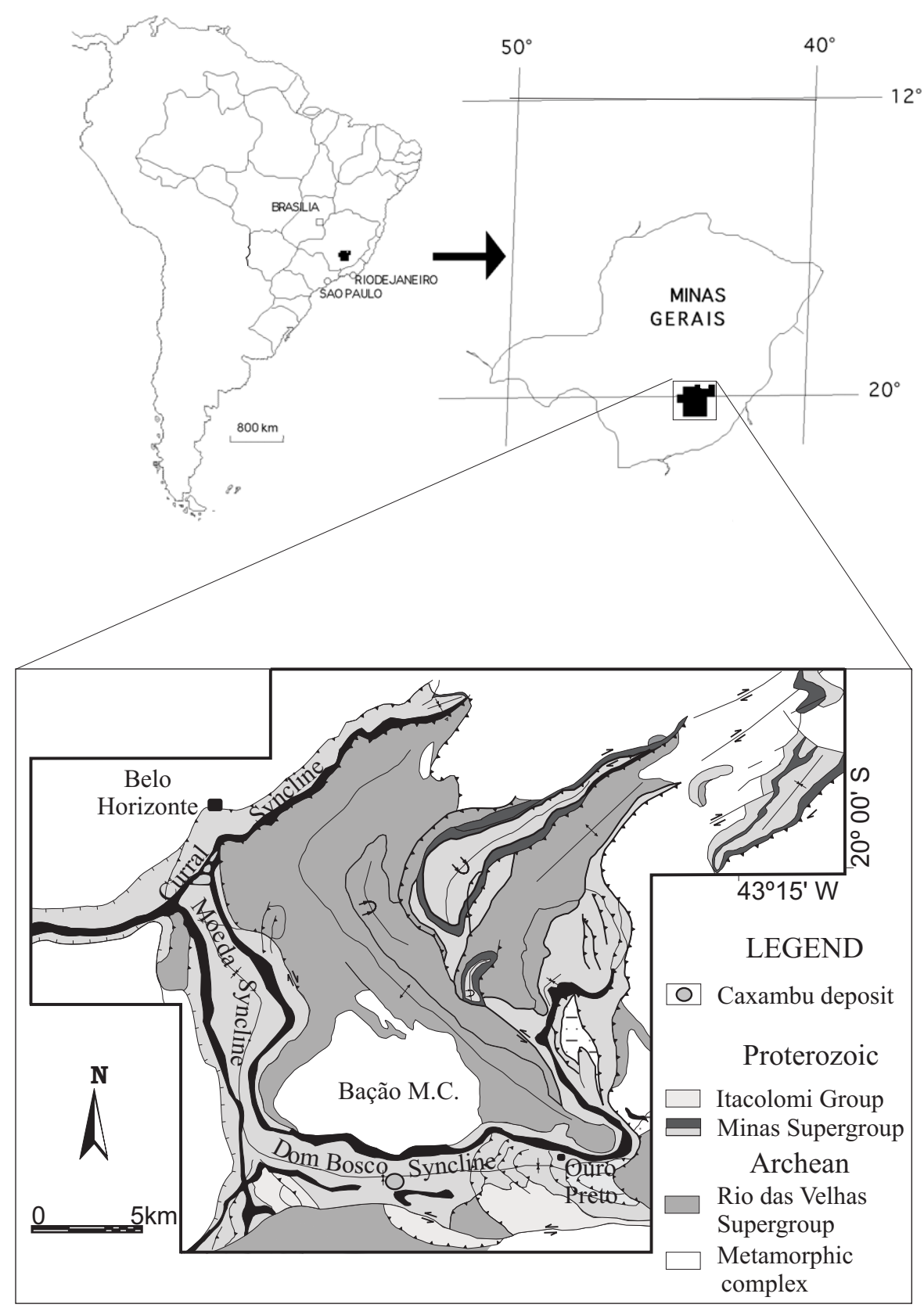

Fig. 1 - Location map of the Quadrilátero Ferrífero showing the Dom Bosco Syncline and the Caxambu Hill deposit.

polemic classification, the origin of these materials was also controversial because various studies, based on field observations, attributed different genesis for them. For the Caxambu deposit, the following hypothesis were reported: volcanic rock weath- ering (Guimarães 1965); weathering from metamorphic rocks (Guild 1957); and, sediments transported by channels (Johnson 1962). Recent studies, based on petrological analysis (Santos 1998, Santos et al. 1999, 2000) revealed that these occurrences were 
formed by gravity mass-flow processes and modified by pedogenic mechanisms.

\section{MATERIALS AND METHODS}

The study of the Caxambu deposit was initiated by field investigations based on description of 6 profiles (sedimentological and pedological aspects) in order to identify the different facies in which 30 representative samples were collected for mineralogical and micromorphological studies.

For mineralogical studies, samples were previously crushed in an agate mortar and ultrasonically dispersed in distilled water. The $<2 \mu$ m fraction was separated from suspension using sedimentation procedures. A mineralogical identification was performed on whole samples and on the clay fraction, as both random and oriented samples, using a Rigaku D/MAX-2B diffractometer with a monochromatic $\mathrm{Cu} \mathrm{K} \alpha$ radiation. $\mathrm{HB}$ index (Hughes and Brown 1979) was measured from the XRD patterns of samples of randomly oriented $<2 \mu \mathrm{m}$ fractions. Differential and gravimetric thermal analyses (DTADGA) were performed on each sample using a SDT 2960 TA DTA-GTA equipment. Additionally, 8 samples were selected for the analysis of heavy minerals by using bromoform separation. Morphological aspects of the clay particles were investigated using a scanning electron microscope (SEM - Jeol JXA-50A).

For micromorphological studies, thin sections were described under optic microscope and description was done with terminologies of Brewer (1964) and Folk (1974).

\section{RESULTS}

\section{Distribution and Macromorphological} Characteristics of the Deposit Facies

Within the Caxambu Hill, the studied clay deposits occur in a NW/SE to N/S oriented graben (Figure 2), originated by syntectonic sedimentation during Tertiary, according to Santos (1998) and Santos et al. $(1999,2000)$.

Utilizing the concepts of facies (Miall 1990,
Walker 1992), associated to the pedogenic and micromorphologic precepts (Brewer 1964), four facies were identified in the Caxambu deposit: fragmentary ( $\mathrm{Fr}$ - diamictite with mud matrix); nodular $(\mathrm{N})$; massive clayey $(\mathrm{Mc})$ and friable clayey $(\mathrm{Fc})$ facies (Figures 2, 3).

\section{Fragmentary facies $(\mathrm{Fr})$}

The facies distribution within the clayey deposits (Figure 2) shows that the fragmentary facies ( $\mathrm{Fr}-$ diamictite with mud matrix) occurs in the lower part and at the borders western and northern of the deposit, in contact with the local basement (Piracicaba Group, Minas Supergroup). This facies has well defined contacts with the nodular $(\mathrm{N})$ and massive clayey $(\mathrm{Mc})$ facies and displays a thickness ranging from $50 \mathrm{~cm}$ to $1 \mathrm{~m}$.

The fragmentary facies is composed of polimitic massive diamictite (Figures 3a, 3b), comprising of lithic fragments (sericitic quartzite, ferruginous quartzite, friable quartzite, phyllite, itabirite, quartz vein) of different sizes ( 3,0 to $30,0 \mathrm{~cm}$ ), associated to some ferruginous lithorelictal nodules $(5 \%)$ with sizes nearly to $2,0 \mathrm{~cm}$. The fragments are angular to sub-rounded (locally with elongate forms) and randomly oriented.

The matrix is clayey with a brown-reddish (Munsell color - 5YR 4/4-25) to yellow-reddish (Munsell color 5YR 4/6) color. Associated to the matrix occur dispersed quartz-grains, with size ranging from coarse silt $(0,06 \mathrm{~mm})$ to coarse sand $(0,6 \mathrm{~mm})$ and some granules. The quartz grains are sub-angular to sub-rounded.

\section{Nodular facies $(N)$}

The nodular facies $(\mathrm{N})$ occurs adjacent to the fragmentary facies ( $\mathrm{Fr}$ ) facies and grades basinwards to the massive clayey facies (Mc). It occurs with a mean thickness of $1.5 \mathrm{~m}$. Specifically at northeastern part of the deposit, a level of quartz stone line (30 m length) occurs separating the nodular from the massive facies.

This facies is constituted of nodules of differ- 


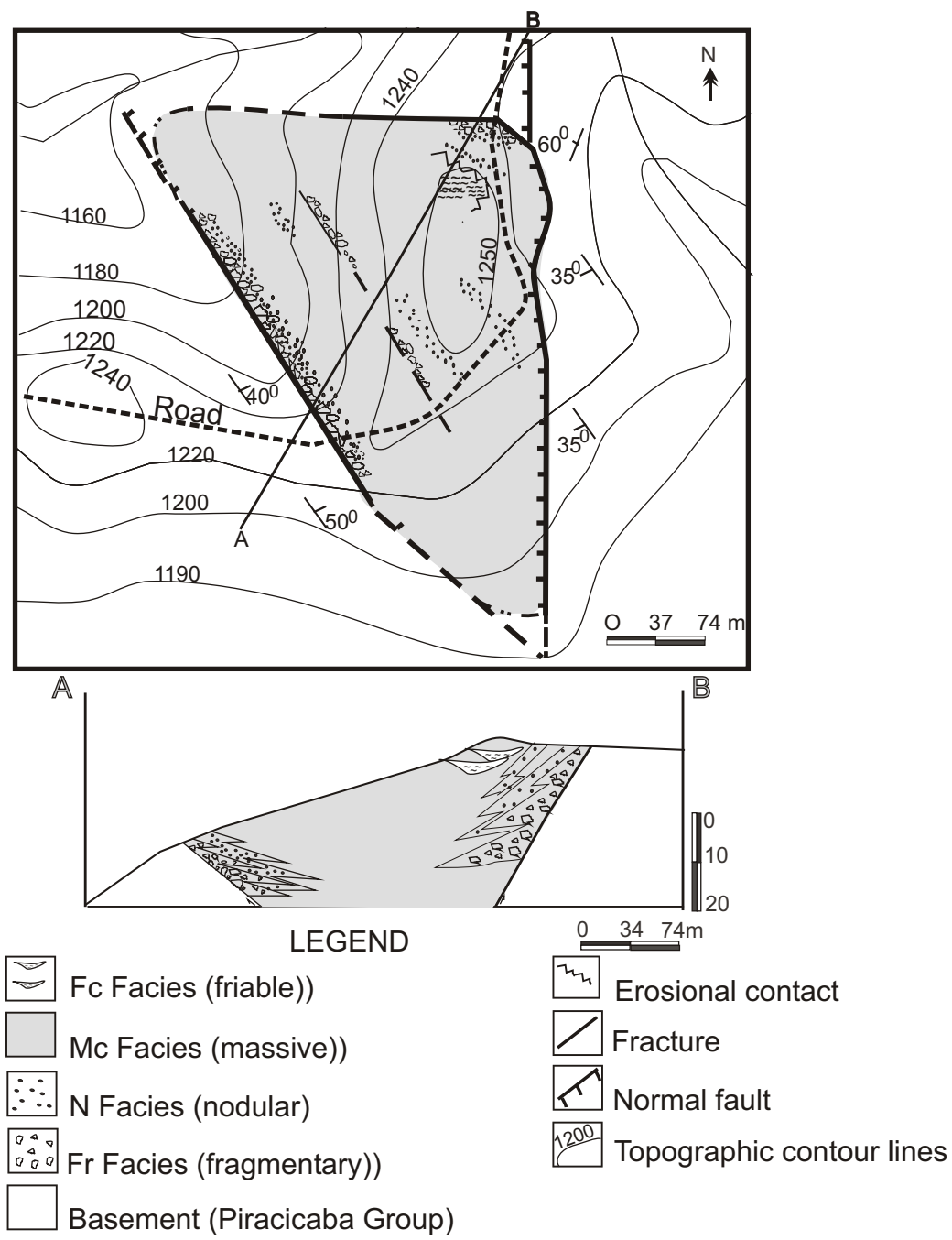

Fig. 2 - Geologic map of the Caxambu hill deposit and the schematic section AB showing the distribution of the facies.

ent sizes $(0,30$ to $2 \mathrm{~cm}$, locally $5 \mathrm{~cm})$ immersed in a clayey matrix (Figures 3c, 3d) with dispersed quartzgrains $(0,5 \mathrm{~mm}$ to $4 \mathrm{~mm}$, occasionally, $5 \mathrm{~mm})$. The nodules are: ferruginous, clayey and lithorelictal. Locally they are associated to lithic sub-rounded fragments of phyllite with size of $\sim 2 \mathrm{~cm}$. The color matrix is brown-reddish (Munsell color $-2.5 \mathrm{YR}$ 4/4), with stains yellow-white, suggesting deferruginization process. Several fault and fracture planes form a regular lattice, in which higher concentration of white stains is observed.

\section{Massive clayey facies (Mc)}

The massive clayey facies occurs in the most basinwards part of the deposit and generally it has a thickness of $\sim 3 \mathrm{~m}$. It is common the intercalation of nodules levels within the massive clay facies, suggesting differentiation of the source of sediments.

The massive clayey facies is characterized by a dark-red (Munsell color - 2.5YR 4/4) to red (Munsell color - 2.5YR 4/6) color, without sedimentary structures. It also present dispersed quartz-grains $(0,25$ to $0,80 \mathrm{~mm}$, locally, $4 \mathrm{~mm})$. A lattice of 


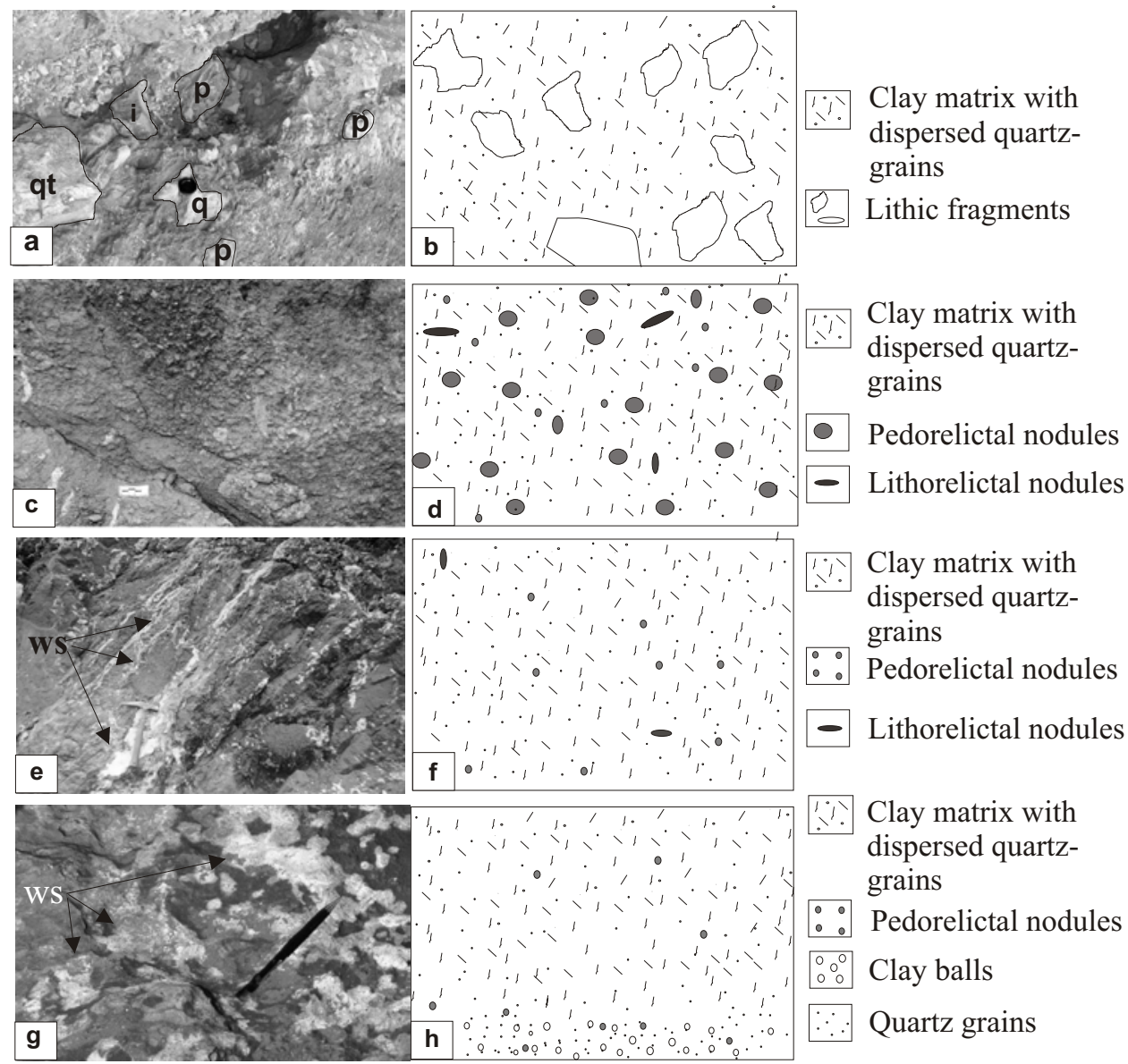

Fig. 3 - Photographs and schematic representation of the facies. a) and b) Fragmentary facies (Fr) showing the lithic fragments: quartz vein (q), quartzite (qt) phyllite (p) and itabirite (i); c) and d) nodular facies $(\mathrm{N})$ showing nodules of different sizes dispersed in a clayey matrix; e) and f) massive clayey facies (Mc) showing the plans of fractures surrounded by white stains (ws); g) and h) friable clayey facies ( $\mathrm{Fc}$ ) showing white stains (ws) in gradational contact with a dark-red clayey matrix.

plans of fractures, forming blocks up to $1 \mathrm{~m}$ large surrounded by white stains (Figures 3e, 3f), occurs as well.

Locally, some plans of fractures are filled with ferruginous material, originating a massive iron crust (duricrust) of thickness ranging from $5 \mathrm{~cm}$ to $10 \mathrm{~cm}$.

\section{Friable clayey facies $(F c)$}

The friable clayey facies, with a mean thickness of $80 \mathrm{~cm}$ and a length of $\sim 5 \mathrm{~m}$, occurs on the top of the deposit inserted in well defined channels that commonly are impregnated with ferruginous material originating a massive iron crust (duricrust) of thickness ranging from $5 \mathrm{~cm}$ to $10 \mathrm{~cm}$.

The friable clayey facies is characterized by a dark-red (Munsell color - 2.5YR 4/4) clay with white to yellowish stains surrounding the fracture/ fault surfaces (Figures 3g, 3h) similarly to the massive clayey facies. The contact of these stains with the dark-red clayey matrix is gradually passing from white to yellowish, then to reddish and finally to dark-reddish. These stains become abundant to the top, getting coalescent to form the wholly upper 
part of the clayey body. The friable clayey facies has dispersed quartz grains $(0,26$ to $4,00 \mathrm{~mm})$, subrounded to sub-angular. Clay balls with diameters of $\sim 0,5 \mathrm{~cm}$ are also associated to the quartz-granules $(3,00$ to $4,0 \mathrm{~mm})$ at the base. A lattice of fractures/faults cuts also this facies, forming blocks of centimeter to metric sizes.

\section{Mineralogy and Micromorphology of THe Deposit Facies}

\section{Fragmentary facies $(\mathrm{Fr})$}

The matrix of the fragmentary facies shows the dominant presence of muscovite and kaolinite, with minor amounts of hematite and goethite. DTA-GTA analysis of the clay fraction shows the presence of kaolinite with a peak temperature of deshydroxylation at $509^{\circ} \mathrm{C}$, suggesting high defect crystals (Mackenzie 1957).

\section{Nodular facies $(N)$}

Microscopic examination (Figure 4a) reveals in the nodular facies a skeleton formed by quartz $(25 \%)$ and muscovite ( $15 \%$ a $20 \%$ ), floating in a clayey matrix and forming a porphyroskelic structure (Brewer 1964). Several types of glaebules are also disseminated within the matrix. In addition, there are heavy minerals (1\%), such as: kyanite, leucoxen, rutile, turmaline and zircon. Except for muscovite, all minerals have sub-angular to sub-rounded shape and show locally corrosions on their boundaries.

The matrix has kaolinitic-hematitic-goethitic composition with traces of muscovite (Figure 4b) forming silasepic and argillasepic structures. It contains irregular dark-brown ferruginous nodules of goethite and hematite composition.

The fabric composition and relationships with the matrix permitted to separate the glaebules into two groups. The first group presents round-shaped nodules with undifferentiated fabric, black and darkred color, with hematite composition and different sizes $(0.30 \mathrm{~cm}$ to $5 \mathrm{~cm})$. These pedorelictal nodules have an irregular distribution and can present yellow cortex of goethite composition with a sharp external boundary with the matrix (Figure 4c). They also can present internal fractures with goethite crystallization in abrupt contact with the matrix. Together with these nodules, also glaebules with concentric fabric occur in rather sharp external boundaries whose surfaces consist of smooth curves related to deferruginization mechanisms. In addition, lithorelictal nodules of phyllite (Figure 4a), quartzite, with or without red/yellow halos and fragments of ferruginous cortex are present.

The second group is characterized by nodules with the same undifferentiated internal fabric, but showing only the enclosing soil fabric (Figure 4d). They have heterogeneous size $(0,064$ to $3 \mathrm{~mm})$ and the transition to the matrix is generally gradual.

\section{Massive clayey facies $(\mathrm{Cm})$}

Optical microscope observation (Figure 4e) revealed that this facies is homogeneous and analogously to the other facies with the same skeletons, without any preferential orientation. The skeleton is composed mainly by quartz (25\%) and secondarily by muscovite $(15 \%)$ and heavy minerals (1\% - kyanite, leucoxen, rutile, turmaline and zircon), all floating in a clayey matrix. Likewise to the nodular facies, several types of glaebules (lithorelicts and pedorelicts nodules) are present but in minor proportion $(1 \%)$ and in smaller sizes $(0,20$ a $1,00 \mathrm{~mm})$.

The clayey matrix has kaolinite-muscovitehematite and goethite composition (Figure 4f) and a silasepic to argillasepic structure. The ATD-ATG analyses of the clay fraction show the presence of kaolinite with an endothermic peak at $500^{\circ} \mathrm{C}$, suggesting high-defect concentration or small crystal size (Mackenzie 1957, Grim 1968).

\section{Friable clayey facies (Cf)}

Microscopically (Figure 5a) this facies is mainly formed by a quartzose skeleton (45\%) and, secondarily by particles of muscovite ( $2 \%)$, heavy minerals $(2 \%)$ as kyanite, leucoxen, rutile, turmaline, zircon, and, some lithic fragments $(1 \%)$ and nodules (2\%) with high degree of degradation, all dispersed in a kaolinitic matrix. The quartz grains have sim- 

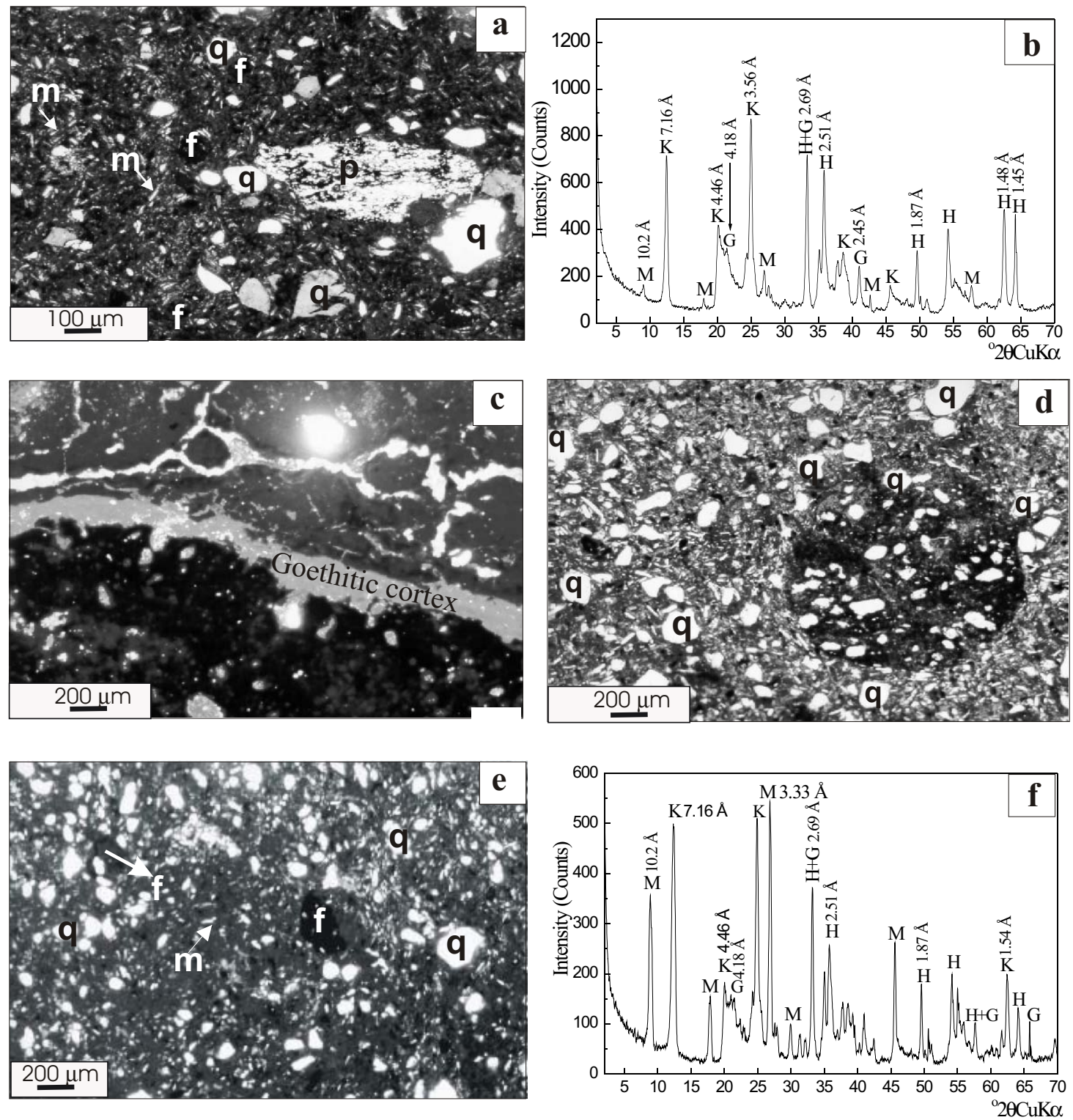

Fig. 4 - Nodular (N) and Massive clayey facies (Mc). a) Optical micrograph (plane-polarized light) of the nodular facies showing the porphyroskelic structure formed by quartz (q) and muscovite $(\mathrm{m})$ skeleton together with lithorelictal nodules of phyllite (p) and ferruginous pedorelictal nodules (f). b) X-ray diffraction pattern ( $\mathrm{Cu} \mathrm{k} \alpha$ radiation) showing the composition of the matrix of the nodular facies. c) Optical micrograph from the border of a ferruginous nodules of the nodular facies showing a cortex of goethite defining a sharp external boundary with the matrix. d) Optical micrograph of a nodule of the nodular facies with undifferentiated internal fabric showing the enclosing soil fabric with quartz (q) skeleton. e) Optical micrograph (plane-polarized light) of the massive clayey facies showing the skeleton with quartz (q), muscovite (m) and ferruginous pedorelictal nodules (f). f) X-ray diffraction pattern (Cu $k \alpha$ radiation) showing the composition of the matrix. $\mathrm{K}=$ Kaolinite, $\mathrm{M}=$ muscovite, $\mathrm{H}=$ hematite, $\mathrm{G}=$ goethite. 
ilar optical characteristics to the underlying facies, but they are more frequent and their surfaces show more dissolution pits.

The matrix has an argillasepic structure, beigewhite color with stains of different sizes and different shades of red: dark-red, red, light red, redyellowish (Figure 5a). These stains have a gradual contact with the beige matrix and contain black to dark-red ferruginous glaebules. The diffuse external boundary with the matrix suggests degradation process due to the deferruginization mechanisms. Mineralogical analyses by DRX of the whitebeige matrix show the dominant presence of kaolinite with minor amounts of muscovite and goethite (Figure $5 \mathrm{~b}$ ). The absence of discrete reflections,

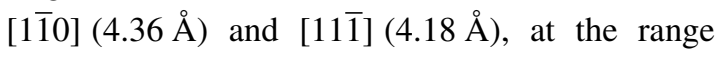
of $20-24^{\circ} 2 \theta$, used to calculate the Hinckley index (Hinckley 1963), indicates the high defect concentration of the kaolinite crystals (Brindley and Brown 1980). As it is not possible to determine the Hinckley index for these high-defect kaolinites, the Hughes and Brown index (Hughes and Brown 1979) was calculated (Figure 5b) and the values ranged from 3-4, typical of kaolinitic soil. These results are consistent with DTA-GTA analysis that show a peak temperature of kaolinite desydroxylation at $\sim 500^{\circ} \mathrm{C}$, confirming a high-defect concentration or small crystal size of the kaolinite. In agreement, SEM analyses (Figure 5c) of the beige-white matrix show island of well defined hexagons of kaolinite, typical of muscovite alteration, surrounded by poorly-defined and small crystals and flakes of kaolinite typical of pedogenic kaolinite (Varajão et al. 2001, Singh and Gilkes 1992).

\section{DISCUSSION AND CONCLUSION}

The studies performed at the clayey deposit of Caxambu Hill showed that several factors influenced its formation and comprise syntectonic deposition, climate, lithology of the source-area and depositional systems. In addiction, pre and post-depositional weathering action is evident on all the facies defined in this deposit.
The deposition of clayey strata occurred in small grabens whose opening was processed in the NW-SE direction, probably reflecting the direction of the faults that affected the crystalline basement and the Proterozoic rocks (Santos 1998, Santos et al. 1999, 2000).

In this context, the fragmentary facies, constituted by polimitic fragments of the underlying rocks, can be related to the processes of rock falls by faulting during the formation of the basin, generating their accumulation at the border of the deposit.

The high iron content of the Caxambu Hill clayey deposits are evidence of subaerial environment conditions ("red beds") and the mineralogical/textural immature characteristics are indicative of gravity mass-flow process, relating these sediment-filled grabens to colluvial deposits under arid/sub-arid climate. This deposition probably occurred in the Tertiary during filling of other basins in the Quadrilátero Ferrífero (Maizatto and Castro 1993, Maizatto 1997).

In this scenario, the climate becomes a fundamental factor during all the evolution of the phases: pre, sin and post-depositional. As the Caxambu deposit is constituted, predominantly, of clayey sediments with subordinate portions of lithic fragments and pedogenic nodules, this association indicates that the rocks of the source area already presented a developed weathered cover, formed under humid climate and originated from the local basement rocks (Piracicaba Group). This lateritic cover was probably composed of a vertical succession of coarse saprolite and fine saprolite horizons overlaid by a pedolith horizon rich in nodules and kaolinitic, goethitic and hematitic materials. The features observed in the nodular facies of the Caxambu deposit showing fragments of nodules, nodules group with recognizable rock fabric (lithorelicts) and soil fabric (pedorelicts) suggest that the most part of the nodules were remobilized pedolith and saprolite materials already available in the source area, in the lateritic profile from higher landscape. Similar features were observed in another clayey deposit from the Quadrilátero Ferrífero (Santos et al. 2003) that is 

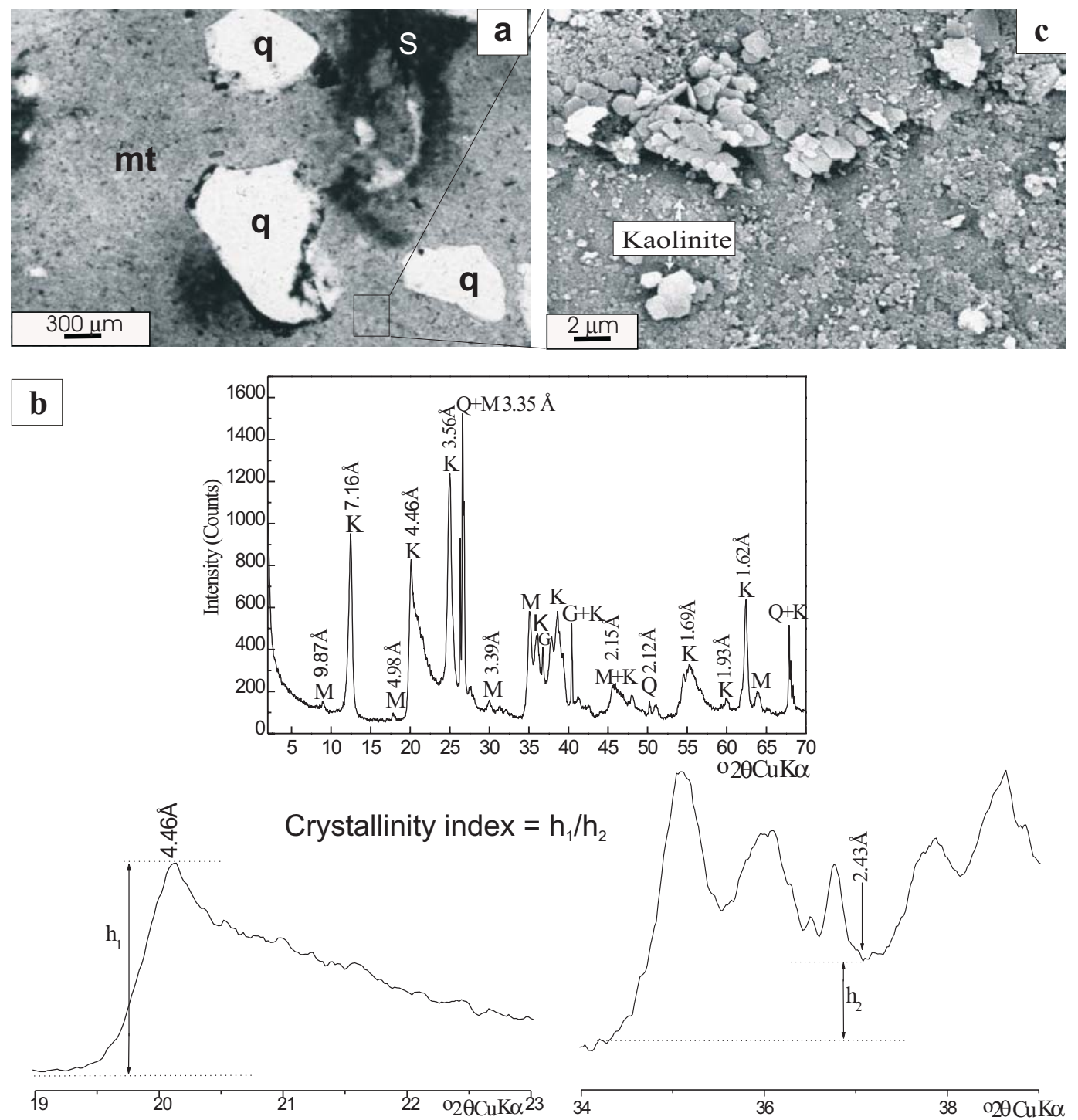

Fig. 5 - Friable clayey facies. a) Optical micrograph (plane-polarized light) showing quartzose (q) skeleton with pits of dissolution dispersed in the beige-white matrix (mt) with stains (s) of different sizes and different shades of red. b) X-ray diffraction pattern (Cu $\mathrm{K} \alpha$ radiation) showing the composition of the white matrix: $\mathrm{K}=$ kaolinite, $\mathrm{M}=$ muscovite, $\mathrm{G}=$ goethite. The ratio $\mathrm{h}_{1} / \mathrm{h}_{2}$, where $\mathrm{h}_{1}$ is the intensity above background of the reflection at $4.46 \AA$, and $\mathrm{h}_{2}$ is the intensity above background at about $2.43 \AA$, indicates the measurement of the crystallinity index according to Hughes and Brown (1979). c) Scanning electron micrograph (SEM) showing hexagons of kaolinite, surrounded by poorly-defined and small crystals of kaolinite.

characterized as an inverse lateritic profile where the nodular facies at the bottom of the deposit is related to the nodular horizon of the lateritic profile from the surrounding landscape The lateritic profile located in higher landscape supply sediments to the basin.
Millot (1964) also shows the mechanical erosion action on the ironcrusts along the valley sides and the formation of pediments with lateritic gravels.

Differently, the presence of a second group of nodules in the nodular facies, with the enclosing soil 
fabric suggest an in situ accretion of iron which accumulated by diffusion or crystallization in the small pores in the matrix due to suitable local chemical conditions (Bocquier et al. 1983, Boulangé 1984, Tardy 1993). The iron could be originated from the saprolite basement and was accumulated by iluviation in clayey pedorelictals and lithorelictals domains of the nodular facies.

In the same way, the sediments that now constitute the massive clayey facies would be related to the mottled clayey zones and inter-nodular portions of the pedolith horizon and to the deeper portions of the alteration profile in the source area. The similarity of this massive clayey facies and the nodular facies, relative to the skeleton composition and to the different kinds of glaebules (lithorelicts and pedorelicts), suggests for both an allochthonous origin by gravitational process and a common supply.

The similar mineralogical skeletal association between the friable facies and the previous facies, together with the analogous micromorphological and pedogenic features, suggest that all the facies have the same allochthonous common origin associated to the gravitational process. The presence of channeled features, clay balls, relictal nodules with high degree of degradation and the higher content in quartz skeleton suggests that the friable clayey facies was generated by the action of unidirectional flow on the materials of the massive clayey and nodular facies. Another fact that corroborates the allochthonous features of this facies is the presence grouping of well defined hexagons of kaolinite pseudomorphs, typical of muscovite alteration from lithorelictal nodules of phyllite, surrounded by poorly-defined and small crystals typical of pedogenic kaolinite. According to Keller (1977) the transport of this clayey mineral is responsible for its morphologic heterogeneity.

The action of secondary processes due to the post-deposition climate changes was probably responsible for the presence of ferruginous duricrusts installed in zones of preferential percolation of water in the fractures, faults and concave surfaces of the channels as for the nodules formed by in situ accretion of iron. The presence of white stains, typical of deferruginization mechanisms, also suggests the weathering action related to a climate less arid. The pedogenic action in all the facies has contributed to obliterate the pre-existing sedimentary structures, leading to the formation of mixture of muddy sediments with an increasing of kaolinite content towards the surface of the clayey deposit.

\section{ACKNOWLEDGMENTS}

The authors thank FAPEMIG, CAPES and CNPq for financial support. We are grateful for reviews of the manuscript by Frank U. H. Falkenhein.

\section{RESUMO}

O depósito argiloso do Morro do Caxambu é produto de uma sedimentação Cenozoica sintectônica em um graben de direção NW/SE. Quatro fácies foram identificadas (fragmentária, nodular, maciça e friável) e suas diferenciações são relacionadas a processos gravitacionais de fluxo de massa. A fácies fragmentária é constituída por fragmentos extraclastos do embasamento local Paleoproterozoico e, por grãos quartzosos de granulometria areia dispersos em uma matriz de composição caulinitamuscovita-goethita-hematita. A facies nodular é formada por nódulos litoreliquiais e pedoreliquiais dispersos em uma matriz semelhante à da fácies fragmentária. A fácies maciça é constituída por grãos de quartzo disseminados em uma matriz caulinita-hematita e goethita com traços de muscovita. A fácies friável difere da fácies maciça por sua morfologia em canal, maior conteúdo em quartzo e caulinita e, pela presença de bolas milimétricas de argila.

A fácies fragmentária foi depositada durante o estágio inicial de abertura da bacia. Em seguida, sob condições semi-áridas, o escorregamento de materiais lateríticos das encostas circunjacentes levou à formação das facies nodular e maciça. A facies friável foi originada do retrabalhamento dos sedimentos argilosos por fluxos unidirecionais. $\mathrm{O}$ aumento em caulinita em direção ao topo da sequência relaciona-se à ação da alteração superficial pósdeposicional. 
Palavras-chave: caulinita, litofacies, micromorfologia, fluxo de massa gravitacional, intemperismo químico.

\section{REFERENCES}

Alkmim FF AND Marshak S. 1998. Transamazonian orogeny in the southern São Francisco Craton region, Minas Gerais, Brazil: evidence for Paleoproterozoic collision and collapse in the Quadrilátero Ferrífero. Precamb Research 90: 29-58.

Bocquier G, Boulangé B, Ildefonse P, NAHON D AND Muller D. 1983. Transfers, accumulation modes, mineralogical transformations and complexity of historical development. In: Melfi AJ AND CARvalho A (eds.), Laterisation Processes. São Paulo, 331-337.

BoulAngé B. 1984. Les formations bauxitiques latéritiques de Côte d'Ivoire. Les facies, leur transformation, leur distribution et l'évolution du modelé. Trav et Docum, ORSTOM, 175, 363p.

BREwER R. 1964. Fabric and mineral of soils. New York: John Wiley \& Sons, 482p.

Brindley GW AND Brown G. 1980. Crystal structures of minerals and their $\mathrm{x}$-ray identification. London: Mineralogical Society, 495p.

FOLK RL. 1974. Petrology of Sedimentary Rocks. Austin: Hemphill Pub. Co., 182p.

Grim RE. 1968. Clay Mineralogy, 2. ed. New York: McGraw-hill, 348p.

GuILD PW. 1957. Geology and mineral resources of the Congonhas do Campo District, Minas Gerais, Brazil. US Geol Surv Prof Paper, 90p.

Guimarães D. 1965. Princípios de metalogênese e geologia econômica. MME/DNPM/DFPM 121.

HINCKLEY DN. 1963. Variability in "crystallinity" values among the kaolin deposits of Georgia and South Carolina. Clays and Clay Min 2: 229-235.

Hughes JC And Brown G. 1979. A crystallinity index for soil kaolins and its relation to parent rock, climate and soil maturity. J of Soil Sci 30: 557-563.

JoHnson AM. 1970. Formation of debris flow deposits. Physical processes in geology: San Francisco, Freeman, 571p.

JoHnson AM. 1984. Debris flow. Slope Instability. In: Brunsden D ANd Prior DB (Eds). New York: J. Wiley, p. 481-504.
Johnson RF. 1962. Geology and ore deposits of the Cachoeira do Campo, Dom Bosco and Ouro Branco Quadrangles, Minas Gerais, Brazil. US Geol Surv Prof Paper (341-B) 37p.

KeLLER WD. 1977. Scan electron micrographs of kaolin collected from diverse environments of originIV. Georgia kaolin and kaolinitization source rocks. Clays Clay Min 25: 311-345.

Lowe DR. 1982. Sediment gravity flow: II. Depositional models with special reference to the deposits of highdensity turbidity currents. J Sed Petrol 52: 02790297.

MackenZIE RC. 1957. The differential thermal investigation of clays. London: Mineralogical Society, $456 \mathrm{p}$.

Maizatto JR. 1997. Análise paleoecológica e bioestratigráfica dos sedimentos cenozóicos da Bacia do Gandarela, Quadrilátero Ferrífero - Minas Gerais com base nos aspectos palinológicos e sedimentares. MSc Thesis, UFOP - University Federal of Ouro Preto, Brazil, 183p.

Maizatto JR and Castro PTA. 1993. Origem e evolução da bacia do Gandarela-Quadrilátero Ferrífero, Minas Gerais. In: SimP. NACIONAL dE Estudos Tectônicos, SBG, Anais... Belo Horizonte, 1993, 12: $325-329$

Miall AD. 1990. Principles of Sedimentation Basin Analysis, 2. ed. New York: Springer-Verlag, 668p.

Middleton GV and Hampton MA. 1973. Sediment gravity flows: mechanics of flow and deposition. In: Turbidites AND DEEP-WATER SEdimentation, Soc. Econ. Paleontologists Mineralogists, Pacific Section Short Course Lecture Notes, p. 1-38.

Millot G. 1964. Géologie des argiles altérations sédimentologie géochimie. Paris : Masson \& Cie, 425p.

Munsell Soil Color Charts. 1975. Baltimore, Macbeth Division of Kollmorgen Corporation.

NAHON D. 1986. Evolution of iron crusts in tropical landscapes. In: RATES OF CHEMICAL WEATHERING OF ROCKS AND MINERALS. London: Academic Press, p. 169-191.

Santos MC. 1998. Gênese dos Corpos Argilosos do Morro do Caxambu e da Mina do Vermelhão, Sinclinal Dom Bosco, Quadrilátero Ferrífero, Minas Gerais, Brasil. MSc Thesis, UFOP - University Federal of Ouro Preto, Brazil, 176p. 
Santos MC, Varajão AFDC, CASTro PTA AND MoREIRA APA. 1999. Gênese dos "depósitos argilosos" da Mina do Vermelhão e do Morro do Caxambu, Sinclinal Dom Bosco, MG. In: Simp de Geologia de Minas Gerais, Simp de Geologia do CentroOeste, SBG/Núcleo Brasília, Resumos Expandidos... 1999. p. 40.

Santos MC, Varajão AFDC, Castro PTA and MoREIRA APA. 2000. Sistemas deposicionales de mudstones del sinclinal "Dom Bosco", (Mina do Vermelhão y Morro do Caxambu), Quadrilátero FerríferoMG, Brasil. In: Cong Latinoamericano de Sedimentología, 2 Reunión Argentina de SedimenTOLogía, Anais... Mar Del Plata, 2000. p. 162-163.

Santos MC, Varajão AFDC And Yvon J. 2003. Gênesis of clayey bodies in Quadrilátero Ferrífero, Minas Gerais, Brazil. Catena (in press).

Singh B AND Gilkes RJ. 1992. An electron optical investigation of the alteration of kaolinite to halloysite. Clays Clay Min 40: 212-229.
TARDY Y. 1969. Géochimie des altérations. Étude des arènes et des eaux de quelques massif cristallins d'Europe et d'Afrique. Mémoire Sérvice Carte Géologique, Alsace Lorraine, 31: 199p.

TARDY Y. 1993. Pétrologie des latérites et des sols tropicaux. Paris: Masson, 459p.

TARDY Y AND NAHON D. 1985. Geochemistry of laterites, stability of Al-goethite, Al-Hemathite and $\mathrm{Fe}^{3+}$ kaolinite in bauxites and ferricretes: an approach to the mechanism of concretion formation. Am J Sci 285: 865-903.

VARAJÃo AFDC, Gilkes RJ And HaRt RD. 2001. The relationships between kaolinite crystal properties and the origin of materials for a Brazilian kaolin deposit. Clays Clay Min 49/1: 45-59.

VARAJão CAC. 1991. A questão da ocorrência das superfícies de erosão do Quadrilátero Ferrífero, Minas Gerais. Rev Bras Geoc 21: 131-145.

WALKer RG. 1992. Facies Models: Response to sea level changes. RG Walker and NP James (Eds) New Foundland: Geological Society of Canada, 454p. 